\title{
ALIGNMENT OF PROJECT MANAGEMENT WITH BUSINESS STRATEGY IN CONSTRUCTION: EVIDENCE FROM THE TURKISH CONTRACTORS
}

\author{
Cenk BUDAYAN ${ }^{\mathrm{a}, \mathrm{b}}$, Irem DIKMEN ${ }^{\mathrm{c}}$, M. Talat BIRGONUL ${ }^{\mathrm{c}}$ \\ ${ }^{a}$ Deprtment of Civil Engineering, Yildiz Technical University, 34220 Istanbul, Turkey \\ ${ }^{b}$ School of Built Environment, Salford University, Greater Manchester, U.K. \\ ${ }^{c}$ Department of Civil Engineering, Middle East Technical University, 06800 Ankara, Turkey
}

Received 26 Jun 2012; accepted 07 Aug 2012

\begin{abstract}
The importance of fit between an organization's implementation of project management (PM), and its business level strategy is emphasized in the literature. However, there are a limited number of studies investigating the relationship between business level strategy and implementation of PM in the construction industry. This paper aligns one of the business strategies, namely differentiation, with the PM process. A framework representing differentiation in the construction industry is proposed in this study. Structural equation modelling (SEM) is used to validate the relationship between differentiation and the PM process. The results show that a relationship between differentiation strategy and PM exists. The two types of differentiation are revealed, namely "product variety and speed-related differentiation" (PSD) and "quality and image-related differentiation" (QID). The companies trying to differentiate based on PSD should focus on cost, time and quality management. Change management and project planning are identified as important drivers of differentiation based on PSD. On the other hand, the companies trying to differentiate on QID should consider health, safety and environmental issues as well as quality. Companies should also manage their resources effectively to support the PM process that in turn leads to successful differentiation. Companies can utilize the research findings as a guideline while formulating their differentiation strategies.
\end{abstract}

Keywords: strategic alignment, differentiation, competitive advantage, project management.

\section{Introduction}

The importance of strategic management for construction companies has long been stressed by many researchers (Chinowsky, Meredith 2000; Tan et al. 2012; Warszawski 1996). However, these studies focus on the application of strategic management at the business level, whereas, there exist studies stating that the strategic priorities at the functional level should also be considered to implement the business level strategies properly (Joshi et al. 2003; Srivannaboon, Milosevic 2006). Although the functional strategies such as research and development, production, and human resource management are mainly considered in examining the alignment with business level strategy; in recent years, PM has been determined as an important functional level strategy (Srivannaboon, Milosevic 2006). Therefore, the researchers advise that the companies should rethink the implementation of PM and align their PM with the business strategy (Shi 2011). The construction industry is a project-based industry; therefore, most of the managers focus on planning and controlling the resources within the framework of the project (Chinowsky, Meredith 2000). As a result of this, most construction companies focus on PM rather than strategic management, which leads to poor strategic management. Whereas companies working in project based industries can meet strategic and operational challenges through working on projects smartly (Longman, Mullins 2004).

In the literature related to the alignment of PM with business strategies, most studies consider the importance of project portfolio management, and they concentrate on evaluating, prioritizing, and selecting projects in line with a specified strategy (Englund, Graham 1999; Meskendahl 2010). However, in recent years, researchers have explored the alignment of PM with business level strategies more comprehensively. For instance, Srivannaboon and Milosevic (2006) classify business level strategies according to Porter's generic typology and align them with PM by using a case-study methodology. They use Shenhar's strategic project leadership framework for determining the PM elements. According to this framework, PM consists of project strategy, organization, process, tools, metrics and culture. Additionally, CookeDavies et al. (2009) tries to align PM systems with strategy by using a case-study methodology. They also use Porter's generic typology for classifying the business

Corresponding author: Cenk Budayan

E-mail: budayan@yildiz.edu.tr 
strategy and "Value of Project Management" study (Thomas, Mullaly 2008) in determining the elements of the PM systems. The elements of PM systems that should be aligned with the business strategy are identified as policy, people, structure and process. As it can be observed, these two studies concentrate on the process as one of their PM elements. This shows the importance of process during the alignment of the business level strategy and PM. By elaborating the PM process performed in the construction projects, valuable information can be provided about how the construction companies can achieve business level strategies through the PM process.

There exist many perspectives on strategy; however according to Parnell (2008), three perspectives in particular, based on the studies of Steiner (1979), Mintzberg (1987) and Porter (1985), are noteworthy. Steiner (1979) suggests that a strategy consists of the important actions of the top managers to achieve the missions of the company. Mintzberg (1987) defines strategy as a plan, ploy, pattern, perspective, or position according to various managerial intentions and emphasizes the link between strategy and planning. Porter (1985) defines strategy as "about being different", in other words, delivering a unique mix of value by choosing a different set of activities. According to Porter's "generic competitive strategies" typology, companies have basically two competitive modes, namely, cost leadership and differentiation. Porter's generic typology is used in order to classify the business level strategy in this study as Porter's approach to strategy has received the attention of many researchers and has been applied to various industries. In addition, Porter's framework overlaps with other developed typologies (Kim et al. 2004).

Due to competitive tendering in which the contract is awarded to the lowest bidder, the cost leadership strategy is widely adopted in the construction industry. Therefore, the construction companies are well experienced and familiar with the cost leadership strategies. On the other hand, most of them do not know how to differentiate themselves from the other construction companies. Whereas, studies such as Kale and Arditi (2003), Cheah et al. (2007) and Dikmen et al. (2009) state that the construction companies following a differentiation strategy can show superior performance. The construction companies can impede competitive forces, which determine the industry profitability and influence them in its favour by applying a differentiation strategy (Kale, Arditi 2003). In addition, despite the wide use of competitive tendering in the construction industry, the selection of the lowest bidder is stated as a prime reason for project delivery problems, as the contractors try to compensate their losses by submitting claims and reducing their quality of work (Hatush, Skitmore 1997). A new approach, namely the economically most advantageous tender approach, is sometimes used in determination of the contractor in projects. Therefore, companies do not only compete on cost but also other criteria like quality, aesthetic value, environmental impact, and safety record, etc. (Perng et al. 2006), which in turn increases the importance of their differentiation strategies in order to achieve competitive advantage.

The researchers show the importance of alignment between business level strategies and PM systems and state that the process is one of the elements of PM systems in the achievement of a business level strategy. However, in these studies, the alignment between the PM process and the business level strategy is not elaborated, since in each industry, different activities are performed in the PM process. In this study, in order to elaborate this alignment, differentiation strategy and PM process performed in the construction industry are considered. In other words, the activities performed in the PM process which affect the achievement of differentiation strategies, and vice versa, are considered by using structural equation modelling.

\section{How construction companies can differentiate}

Differentiation can be established only if differentiation creates value to customers, otherwise the companies cannot ask for higher prices for the products/services that exceed the costs incurred by the firm (Porter 1980). The companies trying to differentiate should understand what the customers want, how they choose the product/ service, and what their motivations are for identifying opportunities of profitable differentiation (Grant 1995). Therefore, the key buying criteria of the clients should be considered intensively for identifying how the construction companies can differentiate. Common evaluation criteria in the construction management literature are stated as quality, cost and time. Kale and Arditi (2003), Tan et al. (2012) also considered these criteria as differentiation methods for construction companies. In addition, Mccabe (2010) stated cost as one of the potential ways for construction companies to differentiate. Moreover, Cheah et al. (2007) identified quality as a supporting component of differentiation for construction companies. However, quality in the construction industry is related to both the service and the product (Yasamis et al. 2002). Mintzberg and Quinn (1998) and Warszawski (1996) considered the quality of service and product as separate ways to differentiate for project based industries. Furthermore, Mccabe (2010) accentuated the potential of service as differentiators for construction companies.

Kale and Arditi (2003) selected innovation attributes of products/services as ways of differentiation for the construction companies in common evaluation criteria. Hartmann (2006) also mentioned that innovative ideas lead to the potential for differentiation in construction companies. In addition, Cheah et al. (2007) considered advanced technology as an important component of a differentiation strategy for Chinese construction companies. Tan et al. (2012) stated that offering innovative project management methods is one of the strategic behaviors of differentiation strategy. The importance of marketing 
and image is mentioned by many authors, like Mintzberg and Quinn (1998), Fombrun (1996). Reputation is also considered as a differentiator in the literature (Cheah et al. 2007; Mccabe 2010; Tan et al. 2012).

Consequently, construction companies can differentiate themselves by reducing the costs in their operation and administrative activities, delivering the constructed facilities on time or ahead of the schedule, improving their service quality and product quality, applying innovative solutions to their procedures and processes, and creating a positive corporate image. In other words, the ways that a construction company can differentiate are defined in six categories: cost, time/schedule, service quality, product quality, innovative solutions and positive corporate image.

\section{Project management process}

Process is considered as an important element of PM in determination of alignment between the business strategy and PM. In addition, Porter (1980) state that the companies can differentiate themselves by creating uniqueness in their value chain. To reveal the construction project process, the Generic Design and Construction protocol (GDCPP) developed by Salford and Loughborough Universities in conjunction with a number of industrial collaborators (Kagioglou et al. 2000) is used in this study. According to GDCPP, the construction project process is divided into four broad categories, namely preproject stage, pre-construction stage, construction stage and post-completion/construction stage. In addition, the process is elaborated with 270 level-two activities within the 10 phases. Since, it is very difficult to consider all these activities in the same model and provide data about all these activities, in this study only construction stage is considered. According to GDCPP, construction stage consists of five broad activities, namely resource management, cost management, quality management, time management and health and safety management. In addition, some of the researchers propose that quality management systems should consider safety and health, since these have common grounds with quality management (Hamid et al. 2004). In order to avoid overlap between these two management activities, aforementioned activities are considered under quality management. Therefore, four broad activity categories are determined. To identify the relationships between these activities, the definition of PM is considered. According to Oisen (1971), PM is the application of various tools and techniques for exploiting diverse resources in order to complete one-time and largely unique tasks within established budget, limited time and desired quality. According to the definition, the diverse resources are used to support the realization of time, quality and cost objectives; therefore resource management is considered as support PM activity.

Consequently, it is hypothesized that three sets of drivers, time management activities, quality management activities, and cost management activities, can affect the differentiation ability of the companies directly. Also, effective usage of the resources is expected to influence the efficiency of these activities; therefore, it is hypothesized that the resource management should affect differentiation ability indirectly.

\section{Time management}

In order to determine the time management tasks, a literature survey is conducted. According to Hameri (1997), in order to manage time properly, three time management activities, namely schedule management, schedule monitoring and control and project planning, should be performed. In addition, risk management has a great effect on achieving the time goals and objectives (Akintoye, Macleod 1997). Consequently, four activities are considered under time management title.

Schedule Management: determines the duration of construction so that an estimate of the general conditions or general requirements containing time-related costs can be prepared and included in the project's estimate (Levy 2002). Due to the nature of construction projects, many uncertainties about the project and external factors such as productivity of labourers, environmental, and weather conditions at the inception are present; therefore schedule planners have to make estimates of several parameters that may be the cause of a potential delay, and to complete the project on or ahead of schedule. Preparation of a successful schedule at the start of a project and managing it throughout the project can lead to effective time management.

Schedule Monitoring and Control. Due to the uncertainties about the project and nature of the work, the divergences from the original schedules usually occur, therefore the progress of the projects should be monitored during the project, and the differences between the actual schedule and the planned schedule should be measured.

Project Planning: refers to the identification of activities, and the determination of duration of these activities, precedence relationships and other attributes at the initial stage of the project (Noronha, Sarma 1991). Project planning has a significant impact on meeting the project's time objectives (Sambasivan, Soon 2007).

Risk Management: is a systematic approach for dealing with risk by establishing an appropriate context, setting goals and objectives, identifying and analysing risks, influencing risk decision making, and monitoring and reviewing risks responses (Edwards, Bowen 1998). The construction industry and its clients are widely associated with a high degree of risks due to facing a variety of situations involving many unknown, unexpected, frequently undesirable and often unpredictable factors (Akintoye, Macleod 1997). A direct relationship between effective risk management and project success is acknowledged, since risks are assessed by their potential impact on the project objectives (Baloi, Price 2003); therefore, it is hypothesized that the risk management 
is an important task that complements time, quality and cost management.

\section{Cost management}

Cost management tasks performed throughout a project are stated as change management, cost control and monitoring and claim management by Potts (2008). In addition, risk management is stated as an important task that supports cost management (Potts 2008; Rad 2001). Consequently, four activities are considered as main cost management activities.

Change Management. The excessive changes in design are usually observed during the project due to errors and omissions in design, and changes in user needs or market demand throughout the project (Kanji, Wong 1998). Excessive changes lead to rework, which in turn increase costs. Therefore, the change management is an important activity for a project team in controlling the cost of the project.

Cost Control and Monitoring: is considered as one of the important activity of project cost management (Pmbok 2008). Since, the cost of the project estimated at the pre-contract stage is diverged due to the limited information available in the early stages of a project. Therefore, the cost of the project should be controlled throughout the project by preparing reports; hence, the corrective actions can be performed in a short time, so that the companies can achieve the targeted cost at the end of the project.

Claim Management. The aim of claim management is to ensure compensation of a detriment suffered by one party according to the contract in the execution of the contract (Kululanga et al. 2001). Due to the nature of the construction, the claims are frequently observed during the projects, and higher construction costs can be observed due to the arising claims and disputes (Demkin 2001).

Risk Management. As mentioned before, risk management is an important activity in order to achieve cost objectives; in addition to this, the relationship between cost and successful risk management was stated by authors, such as Akintoye and Macleod (1997), and Kaming et al. (1997). Consequently, risk management is also considered as a task which supports effective cost management.

\section{Quality management}

The construction industry has a reputation for poor quality and service, a bad safety record (Wood et al. 2002), and leading to environmental problems (Shen et al. 2005). In addition, the construction industry is characterized by its non-standardization (Rowlinson, Walker 1995). Therefore, the companies should apply a quality management system considering safety, health, environment and quality which have many common grounds (Dias 2000; Hamid et al. 2004; Molina-Azorín et al. 2009). Within this context; safety, health, environment and quality management should be integrated to assure quality. Consequently, fundamental quality management activities are considered as environmental management, health and safety management, and quality management. Lastly, due to the same reason mentioned for time and cost management, risk management is included in quality management activities.

Environmental Management. Almost in all countries, environmental issues are receiving attention from governments, non-governmental institutions, commercial organizations in most of sectors of the economy and the general public (Ofori 1992). Therefore, the companies can gain strategic advantage by concentrating on environmental issues (Molina-Azorín et al. 2009).

Health and Safety Management. In the construction industry, since certain types of the construction projects are of high risk, most of the accidents are concluded with death or major injury (Snashall 1990). Health and safety issues should be addressed in the quality systems employed by the companies (Thomas, Mullaly 2008).

Quality Management: refers to an approach for achieving and sustaining high quality output in order to satisfy customer needs, precisely and profitably. The companies can impose the benefits of quality management such as improved products and services, reduced costs, more satisfied customers and employees, improved bottom-line financial performance, market share, and productivity (Lai, Cheng 2003). Therefore, a company using different quality management techniques to maximize value for the client has the potential to achieve a strong competitive position.

Risk Management. The impact of risk management on quality is also stated by different authors, such as Lee et al. (2005) and Akintoye and Macleod (1997), leading to the opinion that risk management should also be considered as a task that supports quality management.

\section{Resource management}

It refers to the activities about procurement of required amount of materials at the desired quality, ensuring the availability of resources whenever required, and allocation of the resources to the identified tasks. The fundamental resources for any construction projects are considered as manpower, materials, money and machines called as four M's of construction. Without any of these resources, none of the activities in the project can be performed. Therefore, the management of these resources is important to perform the activities effectively throughout a project. Consequently, it is hypothesized that the management of these resources represent the resource management.

Material Management: refers to the acquisition and storage of supplies with supporting the complete cycle of material flow from purchasing to the distribution of finished products. By means of an effective material management, the companies can increase the quality, avoid delays (Said, El-Rayes 2011), improve productivity, 
prevent financial loses (Thomas et al. 2005) and reduce waste in construction activities (Min, Zhou 2002).

Human Resources Management (HRM). Human beings are the basic resources of construction, and manpower cost forms the major part of total cost of the projects. However, HRM has been undervalued in construction industry due to high cost of HRM, fragmented nature of the industry, mobility of the workforce, shallow management structure applied in the industry, subcontracting and the use of casual labour, attitudes and education of construction managers (Langford et al. 1995). However, HRM should be considered as a strategic activity and thus carried out consistently with the overall business/ corporate strategy (Kazlauskaite, Buciuniene 2008).

Financial Management. With a strong financial management, a firm can track all its cost components more effectively and create greater accountability. In addition, a sound financial management system is a must for surviving in the market especially when the market takes a downward turn. Therefore, a company's financial management skills may help the companies to achieve business strategies (Jiang et al. 2011).

Machinery/Equipment Management. In many developed countries, there has been a move towards a greater use of plant and machinery in building and civil engineering (Wells 2001). Thus, the selection of the appropriate type and size of construction equipment often affects the required amount of time and effort and thus the job-site productivity of a project.

\section{Research methodology}

This research tests whether relationship between achieving a strategy at business level, namely differentiation, and the process performed in construction project is valid or not. In addition, which management activities performed throughout the project affects the realization of the differentiation strategy in the construction industry are tried to be determined.

Firstly, a group of potential respondents are selected from the companies working not only in Turkey but also abroad. The international experience level of the Turkish construction companies is very high. For instance, the number of Turkish construction companies in the top 225 international contractors published by Engineering News-Record is 31 in 2011 (Reina, Tulacz 2011). The respondents are working as general managers, chairmen or heads of business development/ strategic planning divisions in these companies. In order to obtain the experience level of this group about differentiation strategy, the potential respondents are contacted via telephone one by one and experience level of each respondent is evaluated. Due to the low experience level in implementation of differentiation strategy, some of the potential respondents are eliminated. After that, the rest of the group is informed about the questionnaire by means of sending e-mails and are invited to take part in this survey.
A questionnaire composed of two parts, comprising fourteen questions in the first part and six questions in the second part, is designed and posted on the internet for collecting the necessary data. In SEM analysis, the population of interest should be identified explicitly. Therefore, the target section of the construction industry for this survey is determined as medium-big sized Turkish companies; since, due to the limited resources, small-sized construction firms which face severe difficulties in differentiating themselves from their rivals prefer cost leadership strategies in their business process (Kale, Arditi 2003). The average age and total turnover of the companies within the last 3 years are calculated as 34.27 and 775.54 US\$M for the companies involved in this study, respectively. This shows that the selected companies are appropriate for the identified population. Therefore, it can be concluded that the conclusions obtained at the end of the study are valid for the medium-big sized companies.

The respondents evaluate how well their companies perform PM activities in the first part of the questionnaire. Also, the respondents are asked to evaluate how successful their companies are in completing a project on time, at desired product quality, within the determined budget, and creating positive image, offering high quality service and introducing innovative solutions in the second part of the questionnaire. A Likert scale of 1 to 5 , where 1 denotes the lowest level and 5 denotes the highest level is used in these evaluations. In addition, the respondents are allowed to add activities to the PM process and differentiation ways if they think it is necessary. 84 e-mails are sent to inform the potential respondents about the survey, a total of 62 completed questionnaires are returned for data analysis. The response rate of the questionnaire is determined as $73.8 \%$. The reason of high response rate is that the questionnaires are sent to the respondents who would like to participate in this study. This is determined at stage of selection of the potential respondents. When the potential respondents are contacted to evaluate the experience level about differentiation strategy, a question about whether they would like to participate in this kind of research or not is also asked. According to this answer, the questionnaires are sent to the respondents.

\section{Data analysis}

The data collected from a total of 62 questionnaires are analysed by using EQS 6.1, a structural equation modelling software package. The measured, exogenous and endogenous variables used in this analysis are shown in Table 1.

SEM is determined as the most appropriate method by examining the proposed model. Firstly, the model consists of at least five dependent variables, whereas the traditional statistical models can deal with limited number of dependent variables, such as multiple regression can deal with one dependent variable. Secondly, the 
unobserved concepts, such as differentiation are available in the model; in contrast to the traditional statistical methods, SEM can provide the representation of these variables by measured variables. Therefore, the unobserved concepts can be used in the analysis. Finally, hypotheses which propose multiple layers of linkages between variables at a time lead to an advanced analysis, the traditional statistical methods are incapable of conducting this analysis. Consequently, SEM is essential for analysing the validity of the proposed conceptual model.

The latent variables can be obtained by using two methods. In the first method, the latent variables can be identified according to the results (theories) of previous studies. In the second method, these are identified based on the results of the exploratory factor analyses (Hair et al. 2006). Although the variables in this study are identified according to the literature survey, in order to verify these variables, a preliminary exploratory factor analysis with principal component as extraction method is performed. The reason for making such verification is that only a limited number of studies which investigate the drivers and modes of differentiation are available in the construction management literature. Factor analysis is performed for exogenous and endogenous latent variables separately by using SPSS 15 . Table 1 shows factor loadings of the latent variables. As expected and shown in Table 1, the four components of exogenous latent variables, accounting for 66.319 percent of the variance explained, are extracted according to the minimum initial eigenvalue of one. In addition, the adequacy of the data set for the factor analysis is evaluated according to Kaiser-Meyer-Olkin (KMO) measure of sampling adequacy and Bartlett's test of sphericity. These two measures (KMO $=0.712$ and Bartlett's test of sphericity $(\mathrm{P}<0.000))$ indicate that the sample is adequate for factor analysis. The same process is also conducted for the endogenous latent variables. Although the differentiation variable is considered as only endogenous latent variable, two components of differentiation modes are identified according to the factor analysis. These components, accounting for 58.105 percent of the variance explained, are shown in Table 1. Also, this sample is determined as adequate for factor analysis according to the KMO (0.512) and Bartlett's test of sphericity $(\mathrm{P}<0.000)$. By considering the variables involved under each broad factor and literature survey, the first factor and second factor are renamed as "quality and image related-differentiation", and "product variety and speed related-differentiation", respectively. In the literature, this kind of classification related with differentiation is also available, such as Ricart and Portales (2001). Therefore, the proposed model is altered as shown in Figure 1.

According to the results of exploratory factor analysis, the endogenous latent variable is modified.

Table 1. Result of factor analysis of exogenous and endogenous latent variables

\begin{tabular}{|c|c|c|c|c|}
\hline $\begin{array}{l}\text { Variables } \\
\text { (observed variables) }\end{array}$ & Factor loading & $\%$ of variance & $\%$ of variance & Components \\
\hline Project Planning & 0.882 & 18.760 & 18.760 & \multirow{4}{*}{ Time Management } \\
\hline Schedule Monitoring and Control & 0.782 & & & \\
\hline Schedule Management & 0.763 & & & \\
\hline Risk Management & 0.370 & & & \\
\hline Environmental Management & 0.850 & 17.194 & 35.954 & \multirow{4}{*}{$\begin{array}{l}\text { Quality } \\
\text { Management }\end{array}$} \\
\hline Health and Safety Management & 0.849 & & & \\
\hline Quality Management & 0.641 & & & \\
\hline Risk Management & 0.534 & & & \\
\hline Claim Management & 0.856 & 15.939 & 51.894 & \multirow{4}{*}{ - Cost Management } \\
\hline Change Management & 0.793 & & & \\
\hline Cost Control and Monitoring & 0.605 & & & \\
\hline Risk Management & 0.459 & & & \\
\hline Financial Management & 0.872 & 14.589 & 66.482 & \multirow{4}{*}{$\begin{array}{l}\text { Resource } \\
\text { Management }\end{array}$} \\
\hline Material Management & 0.684 & & & \\
\hline Machinery/Equipment Management & 0.553 & & & \\
\hline Human Resource Management & 0.446 & & & \\
\hline Service Quality & 0.715 & & & \multirow{3}{*}{$\begin{array}{l}\text { Quality and } \\
\text { image related } \\
\text { differentiation }\end{array}$} \\
\hline Product Quality & 0.731 & 35.723 & 35.723 & \\
\hline Positive Image & 0.440 & & & \\
\hline Time & 0.602 & \multirow{3}{*}{22.381} & & \multirow{3}{*}{$\begin{array}{l}\text { Product variety } \\
\text { and speed related }\end{array}$} \\
\hline Innovative Solutions & 0.649 & & 58.105 & \\
\hline Cost & 0.438 & & & \\
\hline
\end{tabular}




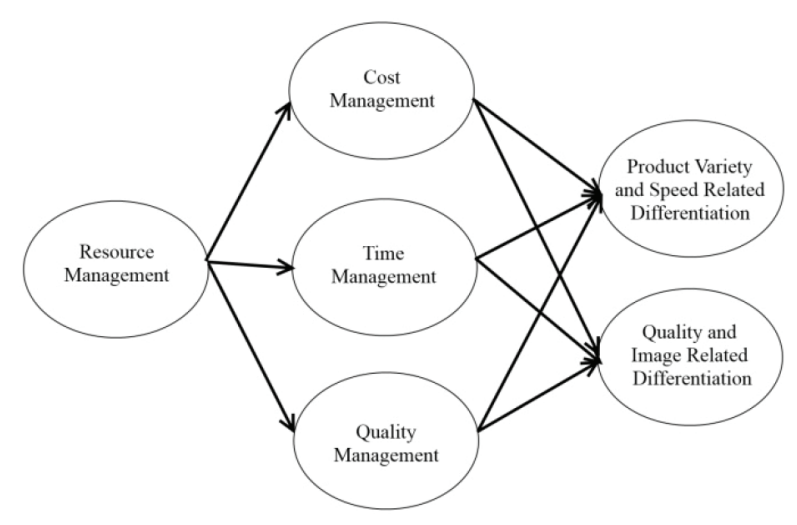

Fig. 1. First proposed model

Therefore, the relationships between the exogenous and endogenous latent variables should be reconsidered in order to avoid unnecessary relationships. One of the strategies used in SEM analysis is proposing a number of alternative a priori models and each model is analysed by using the same set of data. The results are evaluated and compared with respect to several characteristics, including goodness of fit, meaningfulness and interpretability (Hoyle 1995). The model comparison is advised by many researchers, such as Shah and Goldstein (2006), Hoyle (1995). Hence, an alternative model is tried to determine by conducting a literature survey. According to the literature survey, the relationships between the quality management and product variety and speed (Bossink 2002; Lai, Cheng 2003), time management and product variety and speed (Lewis 2005; Sambasivan, Soon 2007); and cost management and product variety and speed (Betts, Ofori 1992; Clough et al. 2000) are observed. However, the relationships between time management, and quality and image related differentiation and cost management, and quality and image related differentiation are not determined obvious. Therefore, an alternative model shown in following figure is proposed. Consequently, in this study two alternative models shown in Figures 1 and 2 are analysed by using SEM.

The reliability of the constructed latent variables should also be assessed; therefore confirmatory factor analysis (CFA) is conducted for each latent variable independently. The estimation method for CFA is selected as maximum likelihood (ML), since the sample size of this study is small. The internal consistency of the latent variables is checked by using the Cronbach's alpha coefficient, an output of CFA. Cronbach's alpha values are calculated as $0.804,0.743,0.787,0.658,0.675$, and 0.690 for "time management", "cost management", "quality management", "resource management", "PSD" and "QID", respectively. Generally, Cronbach's alpha values over 0.7 indicate that the collected data have significant consistency; however the data sets, whose Cronbach's alpha values over 0.6 , are apt for consideration (Sharma 1996). Therefore the factors are considered to have adequate internal consistency. The other indicator for the reliability of the factors is the significance of the variables in the factor loading. According to the factor loadings obtained at the end of CFA shown in Figure 3, the variables that do not have statistically significant loadings should be deleted from the model (Bentler 2006). This evaluation

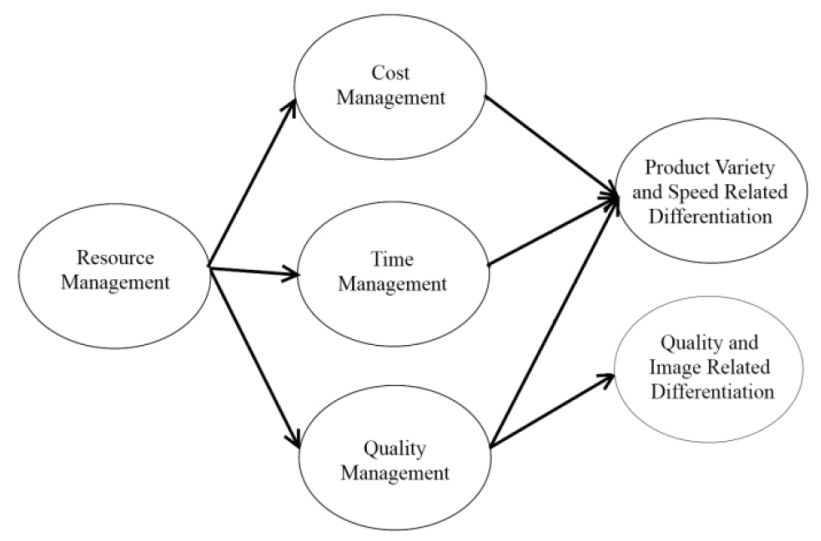

Fig. 2. Second proposed model

\begin{tabular}{|c|}
\hline Material Management \\
\hline Financial Management \\
\hline \hline Human Resources Management \\
\hline \hline Mach./ Equip. Management \\
\hline Risk Management \\
\hline Change Management \\
\hline Claim Management \\
\hline Cost Control and Monitoring \\
\hline Productivity \\
\hline Time \\
\hline Innovative Solutions \\
\hline
\end{tabular}
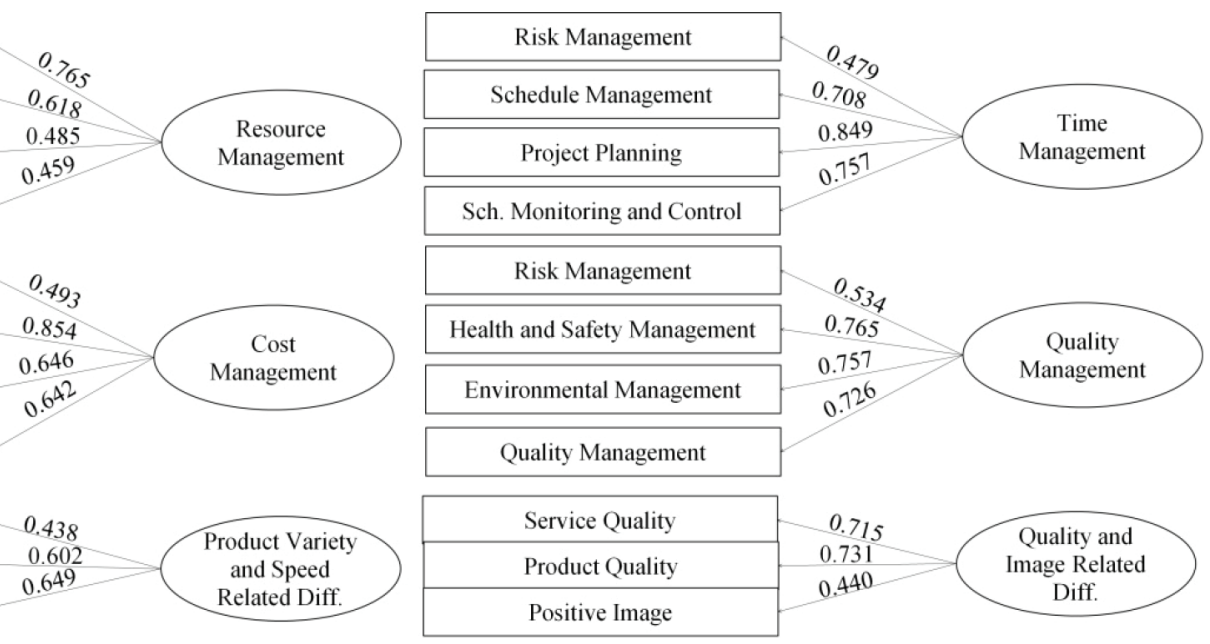

Fig. 3. Factor loadings of the exogenous and endogenous latent variables 
is based on the 0.05 significance level. According to CFA, all variables have statistically significant loadings; therefore no variable is deleted from the model.

In the next step, the models shown in Figures 1 and 2 should be estimated. ML is determined as the estimation method for this step due to the small sample size. In addition, the normality of the data is determined by calculating the Mardia's coefficient. It is calculated as -8.2147 which is far beyond the accepted range of -3 to +3 , in order to be declared as multivariate normal. Thus, the robust method is used to correct the fit indices. According to the d.f., both models (d.f. of first model $=153$, d.f. of second model $=155$ ) are determined as overjustified. In the next step, Non-normed fit index (NNFI), comparative fit index (CFI), Bollen's fit index (IFI), root means square error of approximation (RMSEA) and $\mathrm{X}^{2} /$ degree of freedom (df) are used for evaluating the appropriateness of the model, since these fit indices are the least sensitive to sample size, in other words these fit indices are more appropriate for models whose sample size is small. The fit indices of the models are shown in Table 2. According to these fit indices, the fit between the second model and the data is quiet more satisfactory than the fit between the first model and the data. The reliability of the models is evaluated by considering the Cronbach's alpha of the models and the significance of the paths. The Cronbach's alpha is calculated as 0.861 for both of the proposed models, which shows that the internal consistency of the structural models is satisfied. However, some of the paths, such as the paths between project planning and time management, risk management and time management, machinery/equipment management and resource management, time management and resource management are determined statistically insignificant at 0.05 level for the first model. On the other hand, all path coefficients are determined statistically significant at 0.05 level for the second model. Consequently, the second model whose coefficients of paths are shown in Figure 4 is determined more reliable and selected as the most appropriate model for this data.

Table 2. Fit Indices of the models

\begin{tabular}{lcccc}
\hline Fit indices & Recommended value & First model & Second model & Alternative model \\
\hline Non-normed fit index & $>0.90$ & 0.884 & 0.901 & 0.796 \\
\hline Comparative fit index & $>0.90$ & 0.906 & 0.919 & 0.834 \\
\hline Bollen's fit index & $>0.90$ & 0.914 & 0.925 & 0.846 \\
\hline RMSEA & & 0.066 & 0.061 & 0.087 \\
Lower limit & $<0.10$ & 0.030 & 0.020 & 0.061 \\
Upper limit & & 0.092 & $189.65 / 155=1.223$ & $226.47 / 155=1.461$ \\
\hline$X^{2}$ degree of freedom & Between 1 and 3 & $193.24 / 153=1.263$ & & \\
\hline
\end{tabular}

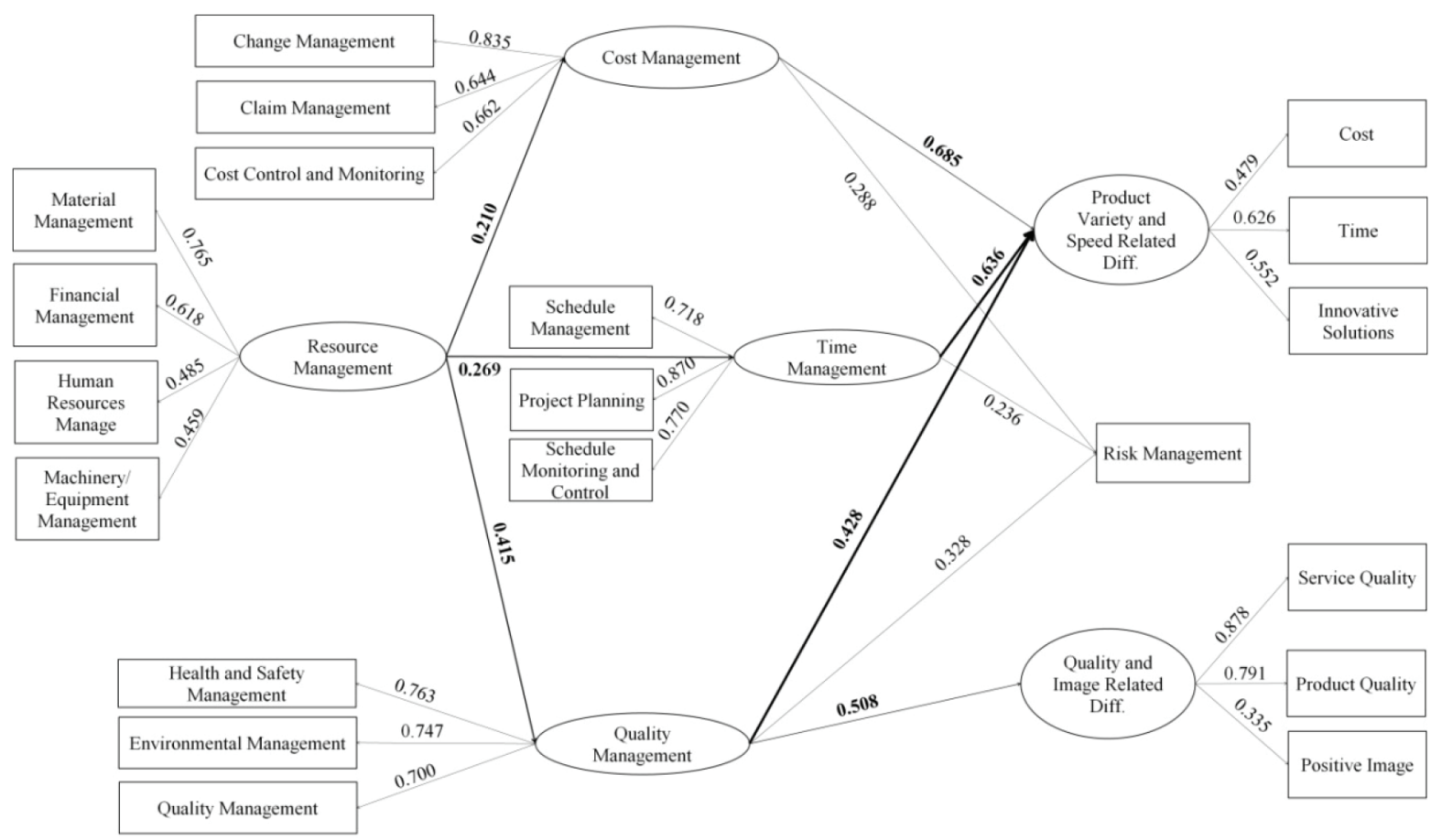

Fig. 4. The structural equation model with factor loadings and path coefficients 
Since the sample size of the data used in this study is below the suggested sample size, Bentler's (2006) recommendation is applied to determine adequacy of the sample size to reject the models. Therefore, the different models are analysed without thinking the logicality of the models by SEM. Fit indices of one of the model in which the paths between the QID and time and cost management, resource management and time, cost and quality management exist are shown in Table 2. According to this table, the fit between the model and data is not good enough to accept the model. In addition, the relationships between the exogenous and endogenous latent variables are determined insignificant. In conclusion, this model is rejected. Consequently, the sample size is determined large enough to conduct studies.

Since the path coefficients placed on the arrows can be used as regression weights, these coefficients are used in determining the significance level of the exogenous latent variables on endogenous latent variables. According to the model, it is observed that "cost management", "time management" and "quality management" are drivers of PSD with a path coefficient of $0.685,0.636$ and 0.428 , respectively. On the other hand, QID is only affected by "quality management "with a path coefficient of 0.508. Also, it is determined that the "resource management" has significant direct effects on "time management", "cost management" and "quality management" with path coefficients of $0.269,0.210$ and 0.415 respectively. In addition, the "resource management" has indirect effects on PSD through "cost management", "time management", "quality management" and on QID through "quality management".

\section{Discussion of findings}

According to the findings of SEM, all of the indicators are determined as valid and they represent differentiation. Therefore, we can conclude that there is a relationship between having a strategy at business level and the PM process. In other words, companies can achieve the business level strategy through PM process and vice versa.

The framework proposed in this study is expected to logically help the construction companies define how decisions taken in the design of the PM process and its fit between their organization's strategy and PM process. In other words, the companies can determine which activities in the PM process should be concentrated on in order to differentiate themselves; in addition they also identify whether the differentiation strategy is a valid strategy by evaluating their PM process. Thus, PM can be transformed from an operational discipline to a strategic discipline.

Two valid differentiation strategies, namely QID and PSD are identified for Turkish construction companies. Therefore, they should decide on how to differentiate before devising a differentiation strategy. Based on the findings, the companies can differentiate based on quality and image, by increasing their product and service quality, and creating a positive image. On the other hand, in order to differentiate based on product variety and speed, they should concentrate on the cost of the projects, complete the projects on time or ahead of the schedule and produce innovative solutions to the problems they face throughout the project.

According to the SEM analysis, "time management" affects PSD, however no direct relationship between "time management" and QID is observed. It appears that the companies that conduct time management activities effectively may differentiate themselves by avoiding delays in the construction, decreasing cost of the projects and providing innovative solutions to problems leading to delays. In addition, among the four time management activities considered within this study, "project planning" is observed to have the highest correlation among these variables. Project planning can provide differentiation opportunities through time management, since the companies can determine the potential problems which lead to delays and can take precautions against these problems in order to minimize their impacts by effective project planning. Project planning is a challenging process due to the limited information at the inception of the project (Andersen 1996) and most companies cannot perform project planning effectively in many cases (Gibson, Gebken 2003). Therefore, the companies should have unique competences and techniques to perform effective project planning.

According to the results of SEM, "cost management" also affects PSD; however it has no direct relationship with QID. This shows that the companies should manage costs effectively in order to achieve a competitive advantage based on PSD. Companies should manage the change orders as they occur throughout the project. The negative impact of change orders on construction productivity and project schedules has also been recognized in the literature (Hanna et al. 2002; Moselhi et al. 2005). In addition, due to the dynamic nature of the construction industry, which leads to errors and/or omissions in design, construction methods, and contract documents, change orders frequently occur throughout a project. Change orders can cause serious problems not only for the contractors but also for the owners. This can lead to disputes between the contractor and owner since both parties blame each other for both the emergence and impact of the change orders (Hanna et al. 2002).

The results of the SEM suggest that "quality management" is associated with PSD and QID. The positive effect of quality management activities on satisfying product and service quality, and creating a positive image is also supported in the literature (Lai, Cheng 2003). Also, there are studies that show that quality management provides higher productivity (Kontoghiorghes, Gudgel 2004), creates organizational conditions to manage innovation effectively (Birkinshaw et al. 2008), and avoids time overruns by providing a healthy construction 
environment, avoiding reworks, and considering environmental issues (Arditi, Gunaydin 1997; Ma, Chan 1999). SEM results also point out that all quality management activities have high factor loadings and therefore contribute to achieving differentiation. However, "environmental management" and "health-safety management" are identified as the most significant indicators. Since, environmental pollution caused by construction activities is a major pollution source (Shen et al. 2005) and the parties involved in a project tend to see environmental issues as the responsibility of other parties (Ofori 2000), this is an expected result. Companies can differentiate their products and services by considering environmental issues and investing in "green" projects. In addition, companies can be perceived as more legitimate in the community due to their attention to environmental issues, which in turn creates a positive image (Pasquire 1999). Companies also achieve legitimacy by assuring workplace health and safety (Kale, Arditi 2003). Therefore, companies can improve their image by providing on-site safety training, providing a safe working environment, provision of safety equipment, and establishing a health and safety department.

The positive effect of the "resource management" on "time management", "cost management" and "quality management" is verified by the data. "Resource management" affects the success of the differentiation strategies indirectly. This indicates that the companies should control the inventory throughout the project, manage the supply chain, establish a sound financial system, hire highly-qualified staff, and select appropriate type and size of machinery to support the PM activities, which in turn affect success in differentiation. Material Management is identified as a critical factor in achieving differentiation in the literature, since the traditional supply chain does not provide a basis for true marketplace differentiation (Bovet, Martha 2000); companies should re-engineer their supply chains in order to achieve product variety, speed, quality and image enhancements in their business (Kumaraswamy et al. 2006). In addition, companies can manage the efficient and effective use of resources by implementing an Enterprise Resource Planning (ERP) system. For instance, Voordijk et al. (2003) concluded that the usage of ERP system can support the construction companies changing from a low-cost strategy to a differentiation strategy.

\section{Conclusion}

This study contributes to a discussion of the fit between an organization's strategy and the way it chooses to manage projects. The findings of this study show that there is a relationship between a business level strategy and PM process, in other words the construction companies can achieve business level strategies by carrying out PM activities. Although, the studies conducted in the literature state that PM process plays an important role in achieving business level strategy, they do not elaborate how the companies can exploit process in achieving business level strategy. However, this study proposed a framework in order to determine the relationships between activities performed in PM process and a specific strategy, namely differentiation.

According to the findings of this study, the Turkish construction industry can differentiate itself in two ways, namely "product variety and speed" and "quality and image". Therefore, construction companies should choose the relevant differentiation mode and try to excel on the major drivers of the selected mode to achieve competitive advantage. Results demonstrate that construction companies can differentiate themselves based on quality and image only if they can establish a quality management system by means of considering quality, health, safety, environmental issues, and risks related to the quality. Especially, the companies should concentrate on "health and safety management" and "environmental management" in order to improve their legitimacy which in turn leads to a more powerful brand.

The companies that try to differentiate themselves in terms of product variety and speed should concentrate on time, cost and quality objectives throughout the project. It appears that the companies that aim to differentiate themselves based on product variety and speed should manage to change orders effectively, thus, they can avoid delays and low productivity as well as disputes between the contractor and owner. In addition, the companies should prepare a good project plan. Finally, the companies should manage their resources effectively in order to differentiate successfully. Material management is identified as an important indicator of resource management according to the factor loadings.

A valid model that explains the relations between PM process and differentiation was constructed by considering Turkish construction companies. Therefore, results obtained in this study can be considered as country specific. However, the companies participated in this study were selected among the companies working abroad. Therefore, the authors believe that the experience of the companies participating in this study related to strategic management is also valuable for the construction companies of other countries. In addition, comparative studies regarding construction companies from different nationalities can be conducted using this model. Furthermore, the parameters identified in this study can be used as a benchmark to conduct similar studies in other project based industries.

\section{References}

Akintoye, A. S.; Macleod, M. J. 1997. Risk analysis and management in construction, International Journal of Project Management 15(1): 31-38.

http://dx.doi.org/10.1016/S0263-7863(96)00035-X

Andersen, E. S. 1996. Warning: activity planning is hazardous to your project's health!, International Journal of Project Management 14(2): 89-94. http://dx.doi.org/10.1016/0263-7863(95)00056-9 
Arditi, D.; Gunaydin, H. M. 1997. Total quality management in the construction process, International Journal of Project Management 15(4): 235-243.

http://dx.doi.org/10.1016/S0263-7863(96)00076-2

Baloi, D.; Price, A. D. F. 2003. Modelling global risk factors affecting construction cost performance, International Journal of Project Management 21(4): 261-269. http://dx.doi.org/10.1016/S0263-7863(02)00017-0

Bentler, P. M. 2006. EQS 6 structural equation program manual. Encino, CA: Multivariate Software, Inc. 418 p.

Betts, M.; Ofori, G. 1992. Strategic planning for competitive advantage in construction, Construction Management and Economics 10(6): 511-532. http://dx.doi.org/10.1080/01446199200000049

Birkinshaw, J.; Hamel, G.; Mol, M. J. 2008. Management innovation, Academy of Management Review 33(4): 825-845. http://dx.doi.org/10.5465/AMR.2008.34421969

Bossink, B. A. G. 2002. The strategic function of quality in the management of innovation, Total Quality Management 13(2): 195-205.

http://dx.doi.org/10.1080/09544120120102432

Bovet, D.; Martha, J. 2000. Value nets: breaking the supply chain to unlock hidden profits. New York: Wiley. 270 p.

Cheah, C. Y. J.; Jian, K.; Chew, D. A. S. 2007. Strategic analysis of large local construction firms in China, Construction Management and Economics 25(1): 25-38. http://dx.doi.org/10.1080/01446190600693450

Chinowsky, P. S.; Meredith, J. E. 2000. Strategic management in construction, Journal of Construction Engineering \& Management 126(1): 1-9.

http://dx.doi.org/10.1061/(ASCE)0733-9364(2000)126:1(1)

Clough, R. H.; Sears, G. A.; Sears, S. K. 2000. Construction project management. $4^{\text {th }}$ ed. New York: John Wiley \& Sons Inc. 360 p.

Cooke-Davies, T. J.; Crawford, L. H.; Lechler, T. G. 2009. Project management systems: moving project management from an operational to a strategic discipline, Project Management Journal 40(1): 110-123. http://dx.doi.org/10.1002/pmj.20106

Demkin, J. A. 2001. The architect's handbook of professional practice. $13^{\text {th }}$ ed. New York, USA: John Wiley \& Sons Inc. $1008 \mathrm{p}$.

Dias, L. M. A. 2000. Management of safety, health and the environment in construction, in Coble, R. J., et al. (Eds.). The management of construction safety and health. Rotterdam: A. A. Balkema, 19-38.

Dikmen, I.; Birgonul, M. T.; Budayan, C. 2009. Strategic group analysis in the construction industry, Journal of Construction Engineering \& Management 135(4): 288-297.

http://dx.doi.org/10.1061/(ASCE)0733-9364(2009)135:4(288)

Edwards, P. J.; Bowen, P. A. 1998. Risk and risk management in construction: a review and future directions for research, Engineering Construction and Architectural Management 5(4): 339-349. http://dx.doi.org/10.1108/eb021087

Englund, R. L.; Graham, R. J. 1999. From experience: linking projects to strategy, Journal of Product Innovation Management 16(1): 52-64. http://dx.doi.org/10.1111/1540-5885.1610052

Fombrun, C. J. 1996. Reputation: realizing value from the corporate image. Boston, MA: Harvard Business School Press. 441 p.

Gibson, E.; Gebken, R. 2003. Design quality in pre-project planning: applications of the project definition rating index, Building Research and Information 31(5): 346-356. http://dx.doi.org/10.1080/0961321032000087990

Grant, R. M. 1995. Contemporary strategy analysis: Concepts, techniques, applications. $2^{\text {nd }}$ ed. Oxford: Blackwell Publishing. $452 \mathrm{p}$.
Hair, J. F.; Anderson, R. E.; Tatham, R. L.; Black, W. C. 2006. Multivariate data analysis. $6^{\text {th }} \mathrm{ed}$. Englewood Cliffs, NJ: Prentice-Hall. 899 p.

Hameri, A.-P. 1997. Project management in a long-term and global one-of-a-kind project, International Journal of Project Management 15(3): 151-157. http://dx.doi.org/10.1016/S0263-7863(96)00051-8

Hamid, A. R. A.; Singh, B.; Yusof, W. Z. W.; Yang, A. K. T. 2004. Integration of safety, health, environment and quality (SHEQ) management system in construction: a review, Jurnal Kejuruteraan Awam 16(1): 24-37.

Hanna, A. S.; Camlic, R.; Peterson, P. A.; Nordheim, E. V. 2002. Quantitative definition of projects impacted by change orders, Journal of Construction Engineering and Management 128(1): 57-64.

http://dx.doi.org/10.1061/(ASCE)0733-9364(2002)128:1(57)

Hartmann, A. 2006. The context of innovation management in construction firms, Construction Management and Economics 24(6): 567-578. http://dx.doi.org/10.1080/01446190600790629

Hatush, Z.; Skitmore, M. 1997. Criteria for contractor selection, Construction Management and Economics 15(1): 19-38. http://dx.doi.org/10.1080/014461997373088

Hoyle, R. 1995. Structural equation modeling: Concepts, issues, and applications. Thousand Oaks, California: SAGE publications, Inc. $289 \mathrm{p}$.

Jiang, A.; Malek, M.; El-Safty, A. 2011. Business strategy and capital allocation optimization model for practitioners, Journal of Management in Engineering 27(1): 58-63. http://dx.doi.org/10.1061/(ASCE)ME.1943-5479.0000033

Joshi, M. P.; Kathuria, R.; Porth, S. J. 2003. Alignment of strategic priorities and performance: an integration of operations and strategic management perspectives, Journal of Operations Management 21(3): 353-369. http://dx.doi.org/10.1016/S0272-6963(03)00003-2

Kagioglou, M.; Cooper, R.; Aouad, G.; Sexton, M. 2000. Rethinking construction: the generic design and construction process protocol, Engineering Construction and Architectural Management 7(2): 141-153. http://dx.doi.org/10.1108/eb021139

Kale, S.; Arditi, D. 2003. Differentiation, conformity, and construction firm performance, Journal of Management in Engineering 19(2): 52-59.

http://dx.doi.org/10.1061/(ASCE)0742-597X(2003)19:2(52)

Kaming, P. F.; Olomolaiye, P. O.; Holt, G. D.; Harris, F. C. 1997. Factors influencing construction time and cost overruns on high-rise projects in Indonesia, Construction Management and Economics 15(1): 83-94. http://dx.doi.org/10.1080/014461997373132

Kanji, G. K.; Wong, A. 1998. Quality culture in the construction industry, Total Quality Management 9(4): 133-140. http://dx.doi.org/10.1080/0954412988758

Kazlauskaite, R.; Buciuniene, I. 2008. The role of human resources and their management in the establishment of sustainable competitive advantage, Inzinerine Ekonomika Engineering Economics 60: 78-84.

Kim, E.; Nam, D.-I.; Stimpert, J. L. 2004. Testing the applicability of porter's generic strategies in the digital age: a study of Korean cyber malls, Journal of Business Strategies 21(1): 19-45.

Kontoghiorghes, C.; Gudgel, R. 2004. Investigating the association between productivity and quality performance in two manufacturing settings, Quality Control and Applied Statistics 49(2): 579-582.

Kululanga, G. K.; Kuotcha, W.; Mccaffer, R.; Edum-Fotwe, F. 2001. Construction contractors' claim process framework, Journal of Construction Engineering and Management 127(4): 309-314.

http://dx.doi.org/10.1061/(ASCE)0733-9364(2001)127:4(309) 
Kumaraswamy, M. M.; Palaneeswaran, E.; Rahman, M. M.; Ugwu, O. O.; Ng, S. T. 2006. Synergising R\&D initiatives for e-enhancing management support systems, Automation in Construction 15(6): 681-692. http://dx.doi.org/10.1016/j.autcon.2005.10.001

Lai, K.-H.; Cheng, T. C. E. 2003. Initiatives and outcomes of quality management implementation across industries, Omega 31(2): 141-154. http://dx.doi.org/10.1016/S0305-0483(03)00021-5

Langford, D. A.; Hancock, G. R.; Fellows, R.; Gale, A. W. 1995. Human resources management in construction. Harlow, Essex: Longman. 208 p.

Lee, S. H.; Peña-Mora, F.; Park, M. 2005. Quality and change management model for large scale concurrent design and construction projects, Journal of Construction Engineering and Management 131(8): 890-902.

http://dx.doi.org/10.1061/(ASCE)0733-9364(2005)131:8(890)

Levy, S. M. 2002. Project management in construction. $4^{\text {th }}$ ed. New York: McGraw-Hill Professional. 427 p.

Lewis, J. P. 2005. Project planning, scheduling, and control: a hands-on guide to bringing projects in on time and on budget. $4^{\text {th }}$ ed. New York: McGraw-Hill. 510 p.

Longman, A.; Mullins, J. 2004. Project management: key tool for implementing strategy, Journal of Business Strategy 25(5): 54-60. http://dx.doi.org/10.1108/02756660410558942

Ma, T. Y. F.; Chan, A. P. C. 1999. The attitude of workers toward construction site safety: a study of site safety in Hong Kong, in Singh, A., et al. (Eds.). Implementation of safety and health on construction sites. Rotterdam: Taylor \& Francis, 63-69.

Mccabe, S. 2010. Corporate strategy in construction. Malaysia: John Wiley\&Sons. 336 p.

Meskendahl, S. 2010. The influence of business strategy on project portfolio management and its success - a conceptual framework, International Journal of Project Management 28(8): 807-817.

http://dx.doi.org/10.1016/j.ijproman.2010.06.007

Min, H.; Zhou, G. 2002. Supply chain modeling: past, present and future, Computers and Industrial Engineering 43(1-2): 231-249. http://dx.doi.org/10.1016/S0360-8352(02)00066-9

Mintzberg, H. 1987. The strategy concept I: five Ps for strategy, California Management Review 30(1): 11-24. http://dx.doi.org/10.2307/41165263

Mintzberg, H.; Quinn, J. B. 1998. Readings in the strategy process. Upper Saddle River, NJ: Prentice Hall. 429 p.

Molina-Azorín, J. F.; Tarí, J. J.; Claver-Cortés, E.; López-Gamero, M. D. 2009. Quality management, environmental management and firm performance: a review of empirical studies and issues of integration, International Journal of Management Reviews 11(2): 197-222. http://dx.doi.org/10.1111/j.1468-2370.2008.00238.x

Moselhi, O.; Assem, I.; El-Rayes, K. 2005. Change orders impact on labor productivity, Journal of Construction Engineering and Management 131(3): 354-359.

http://dx.doi.org/10.1061/(ASCE)0733-9364(2005)131:3(354)

Noronha, S. J.; Sarma, V. V. S. 1991. Knowledge-based approaches for scheduling problems: a survey, IEEE Transactions on Knowledge and Data Engineering 3(2): 160-171. http://dx.doi.org/10.1109/69.87996

Ofori, G. 1992. The environment: the fourth construction project objective?, Construction Management and Economics 10(5): 369-395. http://dx.doi.org/10.1080/01446199200000037

Ofori, G. 2000. Globalization and construction industry development: research opportunities, Construction Management and Economics 18(3): 257-262. http://dx.doi.org/10.1080/014461900370627
Oisen, R. P. 1971. Can project management be defined?, Project Management Quarterly 2(1): 19-36.

Parnell, J. 2008. Sustainable strategic management: construct, parameters, research directions, International Journal of Sustainable Strategic Management 1(1): 35-45. http://dx.doi.org/10.1504/IJSSM.2008.018125

Pasquire, C. 1999. The implications of environmental issues on UK construction management, Engineering Construction and Architectural Management 6(3): 276-286. http://dx.doi.org/10.1108/eb021118

Perng, Y.-H.; Juan, Y.-K.; Chien, S.-F. 2006. Exploring the bidding situation for economically most advantageous tender projects using a bidding game, Journal of Construction Engineering and Management 132(10): 1037-1042.

http://dx.doi.org/10.1061/(ASCE)0733-9364(2006)132: 10(1037)

Pmbok 2008. A guide to the project management body of knowledge (PMBOK guide). $4^{\text {th }}$ ed. Newtown Square, Pennsylvania: Project Management Institute. 275 p.

Porter, M. E. 1980. Competitive strategy: techniques for analyzing industries and competitors. New York: Free Press. $396 \mathrm{p}$.

Porter, M. E. 1985. Competitive advantage. New York: Free Press. 557 p.

Potts, K. F. 2008. Construction cost management: learning from case studies. New York, USA: Taylor and Francis. $306 \mathrm{p}$.

Rad, P. F. 2001. Project estimating and cost management. Vienna: Management Concepts. $121 \mathrm{p}$.

Reina, P.; Tulacz, G. 2011. The Top 225 International Contractors. Engineering News-Record. 63 p.

Ricart, J. E.; Portales, C. 2001. Employment contracts, new organizational forms and competitive advantage for continuous innovation, in Gual, J., et al. (Eds.). Strategy, organization and the changing nature of work. Cheltenham: Edward Elgar Publishing Limited. 250 p.

Rowlinson, S. M.; Walker, A. 1995. The construction industry in Hong Kong. Harlow: Longman Asia Ltd. 162 p.

Said, H.; El-Rayes, K. 2011. Optimizing Material Procurement and Storage on Construction Sites, Journal of Construction Engineering and Management 137(6): 421-431. http://dx.doi.org/10.1061/(ASCE)CO.1943-7862.0000307

Sambasivan, M.; Soon, Y. W. 2007. Causes and effects of delays in Malaysian construction industry, International Journal of Project Management 25(5): 517-526. http://dx.doi.org/10.1016/j.ijproman.2006.11.007

Shah, R.; Goldstein, S. M. 2006. Use of structural equation modeling in operations management research: looking back and forward, Journal of Operations Management 24(2): 148-169. http://dx.doi.org/10.1016/j.jom.2005.05.001

Sharma, S. 1996. Applied multivariate techniques. New York, NY, USA: John Wiley \& Sons, Inc. 225 p.

Shen, L.-Y.; Lu, W.-S.; Yao, H.; Wu, D.-H. 2005. A computerbased scoring method for measuring the environmental performance of construction activities, Automation in Construction 14(3): 297-309. http://dx.doi.org/10.1016/j.autcon.2004.08.017

Shi, Q. 2011. Rethinking the implementation of project management: a value adding path map approach, International Journal of Project Management 29(3): 295-302. http://dx.doi.org/10.1016/j.ijproman.2010.03.007

Snashall, D. 1990. Safety and health in the construction industry, British Medical Journal 301(6752): 563-564. http://dx.doi.org/10.1136/bmj.301.6752.563

Srivannaboon, S.; Milosevic, D. Z. 2006. A two-way influence between business strategy and project management, International Journal of Project Management 24(6): 493-505. http://dx.doi.org/10.1016/j.ijproman.2006.03.006 
Steiner, G. 1979. Strategic planning. New York: Free Press. $400 \mathrm{p}$.

Tan, Y.; Shen, L.; Langston, C. 2012. Competition environment, strategy, and performance in the Hong Kong construction industry, Journal of Construction Engineering \& Management 138(3): 352-360. http://dx.doi.org/10.1061/(ASCE)CO.1943-7862.0000407

Thomas, H. R.; Riley, D. R.; Messner, J. I. 2005. Fundamental principles of site material management, Journal of Construction Engineering and Management 131(7): 808-815.

http://dx.doi.org/10.1061/(ASCE)0733-9364(2005)131:7(808)

Thomas, J.; Mullaly, M. E. 2008. Researching the value of project management. Project Management Institute: Newtown Square, PA. 458 p.

Voordijk, H.; Van Leuven, A.; Laan, A. 2003. Enterprise resource planning in a large construction firm: implementation analysis, Construction Management and Economics 21(5): 511-521.

http://dx.doi.org/10.1080/0144619032000072155
Warszawski, A. 1996. Strategic planning in construction companies, Journal of Construction Engineering and Management 122(2): 133-140.

http://dx.doi.org/10.1061/(ASCE)0733-9364(1996)122:2(133)

Wells, J. 2001. The construction industry in the twenty-first century: its image, employment prospects and skill requirement. Geneva: International Labour Organization. 68 p.

Wood, G.; Mcdermott, P.; Swan, W. 2002. The ethical benefits of trust-based partnering: the example of the construction industry, Business Ethics: A European Review 11(1): 4-13.

Yasamis, F.; Arditi, D.; Mohammadi, J. 2002. Assessing contractor quality performance, Construction Management and Economics 20(3): 211-223. http://dx.doi.org/10.1080/01446190110113693

Cenk BUDAYAN. He is an Instructor in the Faculty of Civil Engineering at Konya Selcuk University. He has completed his PhD study in Middle East Technical University in 2008 with his thesis entitled as "Strategic group analysis: strategic perspective, differentiation and performance in construction". He is a member of Turkish Chamber of Civil Engineers. His main research areas include strategic planning and management, project management, knowledge management, classification methods (e.g. cluster analysis, fuzzy c-means, self-organizing map), and structural equation modelling.

Irem DIKMEN. She is a Professor and Lecturer in the Construction Management and Engineering Division in the Civil Engineering Department in the Middle East Technical University. Her primary research interests include risk management, knowledge management, and strategic management of construction companies and use of IT to improve the construction value chain. She also conducts extensive research in the area of risk management of BOT projects in Turkey. In addition to her research activities, she gives continuing education seminars and consultancy services to construction professionals about international business development and construction risk management.

M. Talat BIRGONUL. He is a Professor and Lecturer in the Construction Management and Engineering Division in the Civil Engineering Department in the Middle East Technical University. Currently, he is the director of Construction Management and Engineering Division of Civil Engineering Department in the Middle East Technical University. Apart from his academic activities, he is an expert witness in Turkish courts and Arbitral Tribunals and gives a claim management consultancy service to leading construction companies. His primary research interests include engineering economy, health and safety, construction planning, macroeconomic aspects of the construction industry and claim management. 